\title{
The Prospects for Tobacco Plain Packaging in Asia: No Longer Smoke up in the Air?
}

\author{
Sarah Herman', Eu-Jin Teo ${ }^{2,3^{*}}$ \\ ${ }^{1}$ Long Island University, New York, USA \\ ${ }^{2}$ The University of Melbourne, Melbourne, Victoria, Australia \\ ${ }^{3}$ Monash University, Melbourne, Victoria, Australia \\ Email: sarah.herman@liu.edu, *ejteo@unimelb.edu.au
}

How to cite this paper: Herman, S., \& Teo, E.-J. (2021). The Prospects for Tobacco Plain Packaging in Asia: No Longer Smoke up in the Air? Beijing Law Review, 12, 45-59.

https://doi.org/10.4236/blr.2021.121004

Received: December 15, 2020

Accepted: February 22, 2021

Published: February 25, 2021

Copyright (c) 2021 by author(s) and Scientific Research Publishing Inc. This work is licensed under the Creative Commons Attribution International License (CC BY 4.0).

http://creativecommons.org/licenses/by/4.0/

\section{(c) (i) Open Access}

\begin{abstract}
The finalization of negotiations over the Trans-Pacific Partnership ("TPP") in October 2015 saw an exemption for tobacco products in the investor-state dispute settlement mechanism. This carve out for tobacco products paved the way for governments to consider introducing plain packaging without the concern that tobacco companies would take legal action against them. Most prominent, however, has been the World Trade Organization's ("WTO's") 2018 ruling affirming a country's right to impose tobacco plain-packaging rules because WTO agreements contain exemptions that permit countries to implement regulations which deemed it necessary to protect the health of their citizens. This article discusses the impact of this decision on initial proponents of tobacco plain packaging including Australia who have introduced statutory limitations on tobacco plain packaging, and the impact that these negotiations will have on opponents of plain packaging, particularly for countries in Asia with establishing trademark regimes. This article presents fresh insight into the legality or otherwise of this tobacco control measure under the Agreement on Trade-Related Aspects of Intellectual Property Rights, relevant international health instruments, and negotiations over the TPP. In particular, it makes pertinent policy recommendations to pave the way forward for legislatures and policy-makers after an analysis of whether plain packaging comes within the scope of the international system for trademark protection as implemented in Thailand, the People's Republic of China and Australia.
\end{abstract}

\section{Keywords}

Tobacco, Plain Packaging, WTO, TRIPS, Free-Trade Agreements

\section{Introduction}

Cigarette packages have been associated with glitzy logos, rich foil sleeves, and 
romanticized language that describes the pleasures within. ${ }^{1}$ Since December 1, 2012 however, this is no longer the case in Australia. ${ }^{2}$ With the weight of scientific evidence at present appearing to indicate that smoking is harmful to health (Siegel et al., 1997; Nadel, Rees, \& Gregory, 2005), many governments are trying to prevent or reduce the incidence of smoking. Conversely and somewhat predictably (and subtly or otherwise), tobacco manufacturers are doing what they legally can in order to mitigate the effect of such regulatory efforts on their bottom line.

A current trend in tobacco control policy is the mandating of so-called "plain packaging", which requires a standardized relevant tobacco product package with a certain appearance and which contains large health warnings. ${ }^{3}$ Plain packaging involves the removal of all attractive and promotional aspects from tobacco product packages and represents a contemporary tobacco control measure that is being considered by a growing number of countries. In its opposition to this measure, the tobacco industry is particularly keen to allege the uselessness of plain packaging in reducing smoking rates and the incompatibility of plain packaging with the trademark provisions of international treaties. Items such as trademarks and logos are not allowed. Canada was the first jurisdiction to try to implement plain packaging in 1994, an effort that failed in large part because of concerns over the trademark rights of tobacco manufacturers, not to mention the potential violation of various relevant international obligations. ${ }^{4}$

In Australia, the future of cigarette packages is literally not that pretty. Pursuant to the Tobacco Plain Packaging Act 2011 (Cth) ("the TPPA"), brand names must be printed in a uniform font on a drab, dark brown background with large, graphic images of gangrenous limbs and diseased organs. ${ }^{5}$ Much to the dismay of tobacco manufacturers and related entities, the High Court of Australia in JT International $S A$ v Commonwealth ${ }^{6}$ found that the plain packaging requirements of the TPPA were not inconsistent with Australian constitutional and intellectual property law. ${ }^{7}$ Whether this case represents the beginning of a legal precedent in favor of plain packaging that will ultimately extend to juris-

\footnotetext{
${ }^{1}$ See, e.g., the packaging portrayed in Atherton (2016).

${ }^{2}$ See Tobacco Plain Packaging Act 2011 (Cth) and, for example, the packaging portrayed in Thomsen (2017).

${ }^{3}$ Tobacco control can take numerous forms and "plain packaging" may be distinguished from statutory requirements to place certain health warnings on tobacco products. While each may impose a restriction on the commercial freedoms of tobacco companies, the latter could be seen as less onerous. A detailed discussion of the various legal issues that are raised by plain packaging may be found in Voon et al. [2012].

${ }^{4}$ For instance, the North American Free Trade Agreement, December 8, 11, 14, Can-Mex-US, reprinted in 32 ILM 289, 6051993 (parts 1 \& 2). At present, there have been numerous complaints submitted to the World Trade Organization concerning the Tobacco Plain Packaging Act 2011 (Cth). A detailed discussion of the issues that are raised in this regard may be found in Voon \& Mitchell (2012a); Voon \& Mitchell (2011b); Mitchell (2010a).

${ }^{5}$ See, e.g., the images displayed in Burgess (2015).

${ }^{6}(2012) 250$ CLR 1 (“JT InternationaP").

${ }^{7}$ For an outline of some of the other legal issues that are raised by the TPPA see, e.g., Mitchell \& Studdert (2012).
} 
dictions other than Australia will depend on a number of factors. In comparison to Asia, Australia could be described as a "dark market" in terms of the potential for revenue growth from the sale of tobacco products. However, regulatory and institutional considerations that are somewhat different to those of Australia would need to be taken into account in, for instance, the People's Republic of China ("PRC") and Thailand (countries that have taken small and tentative steps towards plain packaging), even though the notion of plain packaging would appear to be a concept that is in large part uniform in its various potential incarnations.

This article presents fresh insight into the legality or otherwise of tobacco plain packaging under the Agreement on Trade-Related Aspects of Intellectual Property Rights, relevant international health instruments and negotiations over the TPP. In particular, it makes pertinent policy recommendations to pave the way forward for legislatures and policy-makers.

\section{2. "Descriptive" and Normative Facets of Plain Packaging}

As alluded to previously, "plain packaging" (alternatively known as "generic packaging" or "standard packaging") is a contemporary tobacco control policy measure that requires the exclusion of trademarks, graphics, and logos from tobacco packaging such as cigarette packs. The relevant brand name may be displayed albeit only in simple, unadorned text, in a standard font size, color, and location on the package. ${ }^{8}$ The packaging may not utilize eye-catching colors and is to include only the content and consumer information (such as toxic constituents and health warnings) that are required by law. ${ }^{9}$ Plain packaging thus standardizes the appearance of all tobacco packaging to which it applies in an manner that deliberately disincentivizes the visual and hence, ceteris paribus, consumer appeal of the relevant tobacco products, especially to adolescents, with the aim of reducing the incidence (e.g. prevalence and take-up) of smoking. ${ }^{10}$

Plain packaging requirements raise a number of legal issues, such as whether the relevant measures violate certain constitutional (Hinchliffe, 2013a) or intellectual property rights of, primarily speaking, tobacco companies. Whilst Australia is the only country which to date has successfully implemented domestic plain packaging laws, other jurisdictions (particularly those that are signatories to the World Health Organization Framework Convention on Tobacco Control) $)^{11}$ have taken some steps to implement measures that to some degree regulate the appearance of tobacco products.

\footnotetext{
${ }^{8}$ Note the difference between word marks and non-word marks: Hinchliffe (2013a).

${ }^{9}$ Note that there are various aspects to "tobacco control", which includes regulation of marketing, displays, warnings, excise requirements and, more recently, "plain packaging". In the United States, see, e.g., Family Smoking Prevention and Tobacco Control Act, Pub. L. No. 111-31 Section 102, 123 Stat. 1776 (codified as amended in scattered sections of 5 U.S.C., 15 U.S.C. and 21 U.S.C. (2009)); 15 U.S.C. Section 1333 (tobacco labeling).

${ }^{10}$ See generally, Parliament of the Commonwealth of Australia, Tobacco Plain Packaging Bill 2011: Explanatory Memorandum (House of Representatives).

${ }^{11}$ May 10, 2004, 2302 U.N.T.S. 166.
} 


\subsection{International Health Standards}

In 2005, World Health Organization adopted a framework convention on the distribution of tobacco products ("the Framework Convention"). ${ }^{12}$ This convention, which was ultimately signed by 168 states parties, sought to "reaffirm the right of all people to the highest standards of health." The instigation of the Framework Convention has been described as a "paradigm shift in developing a regulatory strategy to address addictive substances" and one important initiative which separates it from, for example, drug control treaties, is that it addresses demand as well as supply reduction.

Importantly, the Framework Convention (and subsequent protocols) were a response to 1) an increasingly perceived need to combat the "globalization of the tobacco epidemic" and 2) the extent to which this epidemic is said to have been enabled "through a variety of complex factors" that have effects across borders (for example, trade liberalization). ${ }^{13}$ In other words, tobacco companies have been riding on the bandwagon of certain economic forces that could have been seen as desirable in terms of their potential effects on economic development.

The "core demand" provisions of the Framework Convention fall into the two broad categories of price and tax measures. However, other non-price or tax measures to promote reduction include protection from tobacco smoke, the regulation of the contents of tobacco products, the regulation of tobacco product disclosures, the packaging and labeling of tobacco products, education, communication and training (as well as enhanced public awareness), restrictions on advertising, promotion and sponsorship, and demand reduction measures that concern tobacco dependence and cessation.

Of renewed importance is the recent endorsement by the WTO backing the legality of Australia's 2011 measure. On 28 June 2018, the WTO circulated the panel report in the cases brought by Honduras, the Dominican Republic, Cuba and Indonesia in "Australia-Certain Measures Concerning Trademarks, Geographical Indications and Other Plain Packaging Requirements Applicable to Tobacco Products and Packaging". ${ }^{14}$

Prior to this ground-breaking decision, some governments hesitated to implement such measures (Inge Lengton, 2018; Reuters, 2018; Kurohi, 2019; Post Reporters, 2018) after that group of tobacco-producing countries sued Australia for allegedly violating WTO intellectual property rules and setting illegal barriers to trade when it became the first country to implement plain packaging in 2011. Companies such as Philip Morris International Inc. and Japan Tobacco Inc. have argued that tobacco plain packaging rules could make it easier for cigarettes to be counterfeited. The WHO, however, viewed tobacco plain packaging as an evidence-based measure that is a necessary part of a comprehensive approach to tobacco control. This positive affirmation from the WTO panel is therefore like${ }^{12}$ May 10, 2004, 2302 U.N.T.S. 166. See also, World Health Organization (1999).

${ }^{13}$ Id. Cf., Mitchell (2001).

${ }^{14}$ DS435, DS441, DS458 and DS467. 
ly to accelerate global implementation.

So, where did the concept of tobacco plain-packaging begin?

\subsection{Australia Leading the Way?}

In Australia, the TPPA imposes significant restrictions on the color, shape, and finish of retail packaging for tobacco products. One object of the TPPA is to give effect to Australia's obligations as a party to the Framework Convention, as the Act in part is founded upon the power of the Australian Parliament under the Australian Constitution to make laws with respect to external affairs (which has been recognized as including a power to make laws that give domestic effect to international instruments). ${ }^{15}$

The TPPA is superimposed upon the pre-existing Australian regulatory requirements for health warnings (and safety and information standards) that apply to tobacco products and their packaging. The stated objectives of the Act include the improvement of public health by discouraging people from taking up smoking, encouraging people to give up smoking, discouraging people from relapsing if they have given up smoking, and reducing the exposure of people to smoke from tobacco products.

Substantive requirements for the physical features, colors, and finish of retail packaging are imposed by ss 18 and 19 of the TPPA, and by the Tobacco Plain Packaging Regulations 2011 (Cth) ("the TPP Regulations") that have been pursuant to the TPPA. Embellishments on cigarette packs and cartons are proscribed. Packs and cartons are to be rectangular, have only a matt finish, and bear on their surfaces the color prescribed by the TPP Regulations. Absent regulation, the color of the package must be a drab dark brown. Brand, business, company, and variant names for tobacco products that appear on retail packaging must comply with the TPP Regulations. They must not obscure any "relevant legislative requirement" or appear other than once on any of the front, top, and bottom outer surfaces of the pack.

Section 26 of the TPPA imposes a conditional prohibition in relation to the use of trademarks on tobacco products in general, and the use of trademarks on retail packaging of tobacco products is prohibited except pursuant to s 20 (3) of the Act. Section 20 (3) relevantly provides that:

The following may appear on the retail packaging of tobacco products:

1) the brand, business or company name for the tobacco products, and any variant name for the tobacco products;

2) the relevant legislative requirements;

3) any other trade mark or mark permitted by the regulations.

The term "relevant legislative requirement" in s 20(3)(b) includes the health warning required by the Trade Practices (Consumer Product Information Standards) (Tobacco) Regulations 2004 (Cth), or a safety or information standard made or declared under the Competition and Consumer Act 2010 (Cth). Chapter

${ }^{15}$ See, e.g., Commonwealth v Tasmania (1983) 158 CLR 1 (“Dams Case”). 
3 of the TPPA provides for civil penalties in relation to contraventions of the Act.

\subsection{The PRC}

The PRC has around 350 million smokers and maintains seven "world firsts" as a country in relation to tobacco (e.g. it has the world's largest tobacco industry, it is the world's largest tobacco consumer and it has the world's largest tobacco company, which is also the world's most profitable): Fang, Lee, \& Sejpal (2017: pp. 315-316). Whilst no special law on public smoking has been adopted at a national level, at least 20 Chinese cities have introduced local laws banning smoking in public places.

In 1991, the Standing Committee of the National People's Congress ("the NPC") passed the Law of the People's Republic of China on Tobacco Monopoly (zhōnghuá rénmín gònghéguó yāncăo zhuān mài fă) ("Tobacco Monopoly Law") for the purposes of managing the manufacture and business of tobacco products, increasing the quality of tobacco products, protecting consumer interests, and ensuring state revenue. Broadly speaking, the law exercises monopoly control over tobacco commodities and operates a monopoly license system, although it also includes provisions regarding the display of tar yields and general health warnings on tobacco packaging. ${ }^{16}$

Further, the Tobacco Monopoly Law and the 1997 Regulations for the Implementation of the Tobacco Monopoly Law (zhōnghuá rénmín gònghéguó yāncăo zhuān mài fã shíshī tiáolì) ban certain types of advertising of tobacco products (e.g. on radio, TV, and in newspapers or periodicals). The Advertising Law of the People's Republic of China (Advertising Law), promulgated in 1994, supplemented tobacco advertising restrictions by including moving pictures and magazines to the type of media from which tobacco advertising is banned. The State Administration for Industry and Commerce ("the SAIC") issued the Criteria on Censoring Advertisements in 1994, establishing the standards and procedures through which permissible tobacco advertising may be approved.

In 1996, the SAIC issued the Interim Rules on Tobacco Advertising Management in order to further implement the Advertising Law. In addition, SAIC publicly released a series of replies it issued in response to enquiries about tobacco advertising. A number of laws and regulations outline the PRC's smoke-free or restrictive policies concerning smoking in a broad range of public places, including the:

1) Ministry of Health Rules on the Implementation of Public Places Sanitation Administration Regulations;

2) Law on the Protection of Minors (prohibiting smoking in places where minors gather, such as in schools, dormitories, etc.);

3) Rules on the Prohibition of Smoking in Public Transport and Waiting Rooms (issued jointly by six agencies);

${ }^{16}$ Cigarettes and cigars sold within the territory of China should indicate the grade of tar content and

"Smoking is hazardous to your health" (xīyān yǒuhài jiànkāng). 
4) Civil Aviation Administration Rules on the Prohibition of Smoking in Civil Airports and Civil Aircraft; and

5) State Council Regulations on the Administration of Business Premises for Internet Access Services (banning smoking in internet cafes, and public computer lounges).

The central government has pledged to introduce a public smoking ban in its $12^{\text {th }} 5$-year plan over the period 2011 to 2015.

The previously discussed Tobacco Monopoly Law (and its accompanying implementing regulations) from the 1990s still set out general tobacco packaging and labeling requirements in the PRC. In 2007, more specific requirements were issued by the State Tobacco Monopoly Administration and the General Administration of Quality Supervision, Inspection and Quarantine in the form of the Rules on Cigarette Package Labeling in the Territories of the People's Republic of China. The following year, the State Tobacco Monopoly Administration issued its Notice on Interpretation of Relevant Articles in the Rules on Cigarette Package Labeling in the Territories of the People's Republic of China, and on Review and Approval Requirements.

In addition to elaborating on matters such as text, size, colors, etc., the Notice prohibited the use of (potentially misleading) terms such as "mild" and "low tar content" on tobacco packaging. In 2011, the China National Tobacco Corporation published a Notice on Further Strengthening the Degree of Cigarette Package Warning Labeling, and required its subordinate companies to amend their warning labels.

In 2013, China considered the country's first comprehensive national tobacco control law, with a primary goal of controlling the dangers of smoking. ${ }^{17}$ At present, three bills on drafting a law on the prevention and control of tobacco hazards have been forwarded by deputies of the NPC, with another four imminent bills calling for laws on smoke-free areas. These measures to ostensibly curb the use of tobacco stem from ratification by the PRC of the Framework Convention in 2003. ${ }^{18}$ However, these bills do not go so far as to implement plain packaging of tobacco products in the PRC.

The closest that the PRC has come to plain packaging are the labeling laws as set by the State Tobacco Monopoly Administration Warning. Minimum requirements include that labels are text-only, use small six-point type, and feature the same background color as the rest of the pack. Specific health harms of smoking must be spelt out and cover 30 percent of the pack, in Chinese on the front and in English on the back. Tobacco companies are allowed to design their own labels as long as they meet the minimum requirements set by the State Tobacco Monopoly Administration. The China National Tobacco Corporation Notice on Further Strengthening the Degree of Cigarette Package Warning Labeling

\footnotetext{
${ }^{17}$ Reference to "China" in this context refers to the NPC Standing Committee (quán rénmín dàibiăo dà cháng wěi). Note also, the Education, Science, Culture and Health Committee (jiào kē wén wèi tǐ wěiyuánhuì).

${ }^{18}$ The PRC became a Party to the Framework Convention on October 11, 2005.

${ }^{19}$ This is a self-regulation issuance and not a generally applicable legal enactment.
} 
of $2011^{19}$ required subordinate companies of the corporation to abolish the English warning, enlarge the font of the warning characters from $2.2 \mathrm{~mm}$ to $4 \mathrm{~mm}$, and required the color shading between the warning characters and the warning area background to be obviously different.

Whether the plain packaging of tobacco products will eventually be required in the PRC is a question the answer to which is not certain as a result of broader policy and economic considerations. On the one hand, China implements a market economy and is engaged in a process of reform of its monopoly industries (including tobacco), whilst on the other hand it is becoming increasingly concerned over bread-and-butter issues. The PRC now endeavors to build a service-oriented government, and to amplify its medical and healthcare reform on the back of an escalated national health standard (and also to give effect to the Framework Convention). From the dual imperatives of tobacco monopoly reform and tobacco control, a breaking of the tobacco monopoly may appear to be likely.

Generally speaking, in the face of requirements to open markets and improve competitiveness, many jurisdictions have witnessed their tobacco industries move towards increased marketization but also have various regulatory safeguards in place. In various countries, there are specific agencies that supervise tobacco advertising, promotion, warnings, and product and ingredient disclosures so as to meet public concerns to some extent. However, the PRC's existing tobacco monopoly (with its low marketization) does not sit well with contemporary corporate governance and governmental property management. There still is not a fully competitive tobacco market and tobacco monopoly departments are not doing all that might be feasible to contain the health hazards of tobacco.

\subsection{Thailand}

Thailand's proposed tobacco packaging law, the Tobacco Consumption Control Act, looks set to go further than Australia's plain packaging rules in relation to the curtailment of the rights of brand owners. The draft law leaves responsibility for drafting specific regulations to a government body, with s 40 referring to various aspects of the packaging that are to be dealt with (for instance, "the size, color, symbol, label including the character of the displaying of trademark, symbol, picture"). At present, in addition to laws that prohibit advertising and marketing, Thailand's laws that regulate tobacco packaging require that 55 percent of the packaging be covered by graphic health warnings.

The proposed law specifies that manufacturers and importers must package tobacco products "according to the direction of the directing commission". The directing commission essentially comprises of everyone except the tobacco manufacturers, and includes the minister of public health, the permanent secretary and various ministers (such as the ministers of finance and culture) as well as representatives from non-government organizations. The influence of non-government organizations and the exclusion of major tobacco stakeholders may be viewed as noteworthy facets that underlie the draft law. 
The reach of the draft law is broad in various aspects. For instance, s 32 (as currently drafted) essentially states that no one may use a tobacco name or mark (or the name of a tobacco manufacturer) on any non-tobacco products. Accordingly, if a manufacturer has an array of products, any marks registered in International Class 34 for tobacco products may not be used for any products in any class. The ultimate form, and indeed, introduction of the law, however, remains to be seen.

\section{Normative Themes in the Trademark Regime}

A belief may be held in some quarters that tobacco companies have an exclusive entitlement to their trademark rights, to the exclusion of others. Trademarks (as a type of intellectual property) could be said to play a role in the marketing process of an enterprise. In the absence of monopoly conditions or perfectly competitive markets where companies and products are standardized and consumers do not have a real opportunity to make product or price choices, many products face competition and one way of differentiating between sellers and products is by having distinctive trade names and one or more trademarks. ${ }^{20}$

Tobacco is one instance of a long-standing industry where individual enterprises have invested heavily in product differentiation, primarily through marketing pursuits. Strong brands and successful branding (through distinct imagery, identification, and reputation, for example) may be validated through contribution to market share, sales, enhanced goodwill, profit margins, loyalty, and market awareness. However, it could be said that the ultimate success of a brand is founded upon the perceived total value derived by customers from the product to which the brand relates.

Of late, the reach of governments' regulatory ambit in relation to tobacco could be said to have had some far-reaching consequences for tobacco companies. Health warnings and safety and information standards, for example, are now applied to tobacco products (and their packaging) in many jurisdictions in a bid to improve public health by discouraging people from taking up smoking, encouraging people to give up smoking, discouraging people from relapsing if they have given up smoking, and reducing people's exposure to smoke from tobacco products.

In this regard, governmental policy motivations such as consumer protection and promotion of better health would appear to be quite clear in the case of "plain packaging”. As previously discussed, plain packaging greatly restricts the use of trade or other marks in relation to tobacco products. When opposing the adoption by a State of laws or regulations that potentially diminish the value of a trademark, the holder of the trademark is under an initial obligation to show that the relevant measure has the effect of causing consumers to switch to competing goods or services.

Such an obligation is consistent with the ultimate purpose for which the law provides for the grant of trademarks: to allow firms to distinguish their products ${ }^{20}$ See Hinchliffe (2013a) (defining "economic rights" and "economic perspectives"). 
from those of other firms. Unlike copyright and patents (where protection for such intellectual property is justified in substantial part by the perceived value of securing reasonable and limited incentives for creators to invent), trademark law offers incentives for businesses to invest in the quality and uniqueness of their goods and to convey quality through combinations of words, colors, signs, shapes, and other distinguishing marks. ${ }^{21}$ In the United States, at least, patent and copyright law come from the "progress clause" of the Constitution, and are there to create incentives for "promoting progress." ${ }^{22}$ In Australia, the European Union, and Singapore, by comparison, there is less emphasis on these aspects and more emphasis on protecting the value of brands (in an economic sense) if they so warrant it.

One purported social justification (or "public interest") in the case of trademarks therefore is the reduction of information costs for consumers. An underlying motivation for trademark law thus is to prohibit the encroachment by one economic competitor on investments in product distinction that have been made by another competitor. Some tension could ergo be said to appear to arise between property rights (as accomplished through trademark protection) on the one hand, and other values such as, for instance, broader notions of freedom of expression.

In this regard, it is worthwhile to bear in mind the nature of a trademark as a state granted privilege, and the traditionally justifiable role of the state as an information source to, and protector of, consumers in instances of market failure. In particular, the position taken by Australia (and, not to mention, the WTO) with respect to tobacco plain packaging laws appears to seek to reconcile the recognition of property rights in the form of trademarks with a traditional rationale for trademark law of seeking to improve the quality of information in the marketplace. ${ }^{23}$

\section{Trademarks, Health Policy and the Agreement on Trade-Related Aspects of Intellectual Property Rights}

In the international arena, there could be said to be various arguments which would appear to impugn any purported implementation of plain packaging legislation. ${ }^{24}$ In a broad sense however (and particularly in the context of trademark law), it is necessary to have a proper understanding of the scope of what it means to "use" a trademark when the drafting of plain packaging legislation that limits

${ }^{21}$ See G. \& C. Merriam Co. v. Saalfield, 198 F. 369, 373 (6th Cir. 1912); Moseley v. V Secret Catalogue, Inc., 537 U.S. 418, 428 (2003) (“Traditional trademark infringement law is part of the broader law of unfair competition ... that has its sources in English common law”); Hanover Star Milling Co. v. Metcalf, 240 U.S. 403, 412-13 (1916).

${ }^{22}$ U.S.C. Art., Section 8, Cl. 8.

${ }^{23}$ This is an important premise that plays down the property rights that could be argued to vest as a consequence of the trademark regime. See also Landes \& Posner (2003: pp. 166-168).

${ }^{24}$ See Hinchliffe (2013a). See also Report by Daniel Gervais for Japan Tobacco International, Analysis o1 the Compatibility of Certain Tobacco Product Packaging Rules with the TRIPS Agreement and the Paris Convention (November 30, 2010) (“Gervais Report”). Compare, e.g., Memorandum from Lalive to Philip Morris International Management SA, Why Plain Packaging is in Violation of WTO Members' International Obligations under TRIPS and the Paris Convention (July 23, 2009) (“Lalive Report”). 
and displaces certain rights of manufactures and retailers (whilst at the same time creating other obligations on these same entities) is being considered..$^{25}$ Numerous countries (for instance, the PRC, Singapore, Australia, the United States, and Canada) have the right to use a trademark incorporated into their domestic legislation which can prima facie be varied, modified, qualified or eliminated at the legislative will of the government, in contradistinction to a right that is contained in an international treaty. ${ }^{26}$

Putting aside the Paris Convention, ${ }^{27}$ the only significant argument under the Agreement on Trade-Related Aspects of Intellectual Property Rights (“TRIPS") with respect to plain packaging centers around a rather intricate provision, art $20 .^{28}$ One feature of art 20 is its ability to interact with a number of other provisions, including art 8 , which relates to public health considerations. ${ }^{29}$ Advocates and scholars who contest the trademark claims of tobacco companies may seek to focus on public health and even textual reasons to justify expansive public interest regulation such as plain packaging.

In the context of tobacco control, scholars and advocates invoke the Framework Convention and also the International Covenant on Economic, Social and Cultural Rights to justify strong laws that limit the use of tobacco trademarks. Because it has been said that human rights are inviolable, on such a view in the case of a conflict with the former a trademark holder's property interest is necessarily subordinate. Alternatively, if a prohibition concerning the use of property can be justified as being reasonably necessary to the performance by a State of its recognized obligations to protect public health, safety, morals or welfare, then it would normally seem that there is no relevant "taking" of property in this regard (a view that is well in line with the objectives of TRIPS art 8). ${ }^{30}$

Further, according to TRIPS arts 7 and 8 , private remuneration should not be given more weight than social welfare, but a harmonious balance between different interests needs to be struck (Drahos, 1999: p. 355). These articles embody the objectives and principles of TRIPS and acknowledge the public interest element implicit in the intellectual property regime.

\footnotetext{
${ }^{25}$ The interpretation of "use" is important to understand the meaning of "acquire" or "acquisition" of a trademark by a government. See Hinchliffe (2013a) (discussion of "use" under the Agreement on Trade-Related Aspects of Intellectual Property Rights).

${ }^{26}$ Compare, e.g., Gervais Report, [64]; and Lalive Report, [23].

${ }^{27}$ Paris Convention for the Protection of Industrial Property, July 14, 1967.

${ }^{28}$ For an in-depth discussion of the TRIPS-related issues, see, e.g., Mitchell (2010b).

${ }^{29}$ Note that the Paris Convention is silent in relation to public health considerations. Notwithstanding the existence of art 8, the application of TRIPS proved to be problematic in relation to public health measures prior to the adoption of the Doha Declaration. Compare Mitchell \& Voon (2009); Liberman \& Mitchell (2010).

${ }^{30}$ Compare s 15(1) of the TPPA, which provides for the non-application of the Act to the extent (if any) that its operation would result in an acquisition of property from a person otherwise than on just terms. Section 15(2) provides that if, leaving aside section 15, the TPPA would result in such an acquisition of property because it would prevent the use of a trademark or other sign on or in relation to retail packaging of tobacco products, the trade mark or sign may be so used. For a discussion of the differences between, and constitutional validity of, an "acquisition", "taking" or "use" under the Australian Constitution and under the United States Constitution (in particular in relation to the First, Fifth and Fourteenth Amendments), see Hinchliffe (2013a).
} 
Having said that however, some tension (as illustrated by the Doha Declaration on the TRIPS Agreement and Public Health) does exist within TRIPS between the protection of intellectual property rights and the public interest. ${ }^{31}$ There also appears to be some degree of divergence in the approach of courts and legislatures in Australia, the United States, and China in balancing these objectives (Hinchliffe, 2013b). The character (broadly speaking) of the relevant rights and the conditions that inform their creation may be relevant in identifying whether and in what circumstances restriction or regulation of their enjoyment by a law amounts to an impermissible acquisition (in the case of Australia) or taking of property (in the case of the United States). ${ }^{32}$

These considerations, however, may not be apparently relevant in the case of other jurisdictions (for instance, China and Hong Kong). ${ }^{33}$ Yet in a broad sense, national and regional courts and tribunals for the most part have acknowledged in appropriate contexts the less than absolute nature of many property rights and recognized that certain types of public health regulations may be viewed as an intrinsic limit to property. At present however, the relative unpredictability of arbitration and judicial decisions on the appropriate extent of regulation without compensation in the context of plain packaging suggests that scholars, judges, and regulators may have to bear in mind appropriate ways of compensating affected trademark holders (Voon \& Mitchell, 2012b; Mitchell \& Wurzberger, 2011; Voon \& Mitchell, 2011b).

\section{Trans-Pacific Partnership}

In October 2015, it was announced that negotiations over the Trans-Pacific Partnership (TPP) have been completed. While the full text has not yet been released, it has emerged that an exemption in the investor-state dispute settlement mechanism for tobacco products has been agreed. Such a carve out for tobacco products paves the way for governments to consider introducing plain packaging without the concern that tobacco companies would take legal action against them. However, while a blow to plain packaging opponents, it would appear that the battle over the TPP is far from over the agreement still requires ratification by the respective partners and opposition is already growing.

\section{Tobacco Plain Packaging Up in the Clouds?}

Australia is the only jurisdiction to date which has implemented plain packaging legislation (which, as previously noted, prohibits any promotional or branding

\footnotetext{
${ }^{31}$ Ministerial Conference, Declaration on the TRIPS Agreement and Public Health, WT/MIN(01)/DEC/2 (November 20, 2001).

${ }^{32}$ See Hinchliffe (2013a) (discussing the constitutional validity of tobacco plain packaging in the United States, Australia, China, and the European Union).

${ }^{33}$ See id.

${ }^{34}$ Under the TPPA. See also JT International (2012) 250 CLR 1, where the majority of the High Court of Australia found that the TPPA was constitutionally valid on the basis that an "acquisition" (in this case, of intellectual property) on "unjust terms" within the meaning of s 51(xxxi) of the Australian Constitution must involve the accrual of a proprietary benefit or interest. See Hinchliffe (2013a) (discussing the constitutional validity of tobacco plain packaging in the United States, Australia, China, and the European Union). The United States Supreme Court has repeatedly held that the First Amendment's speech protections extend to commercial speech, including tobacco advertising (which accordingly might be relevant to plain packaging, i.e. as a "taking" or "encumbrance"). See Va. State Bd. of Pharmacy v. Va. Citizens Consumer Council, 425 U.S. 748, 762-73 (1976).
} 
messages on tobacco products). ${ }^{34}$ In part, this article has noted the importance of articulating the role of health policy (i.e. broader public rights) when seeking to restrict private rights such as those of trademark-holders. Government policy, economic priorities, and international obligations also have a bearing upon the potential implementation of plain packaging legislation, particularly in Asia. Whether the Unite States and other jurisdictions will take the same approach towards plain packaging as that of Australia remains uncertain but, at least in the PRC and Thailand, some steps (albeit largely small and tentative) could have been said to have been taken in this direction. For now though, the conclusion would appear to be that, notwithstanding the plain harm to health that is wrought by tobacco consumption, a global approach to the plain packaging of tobacco products is still, at least temporarily, (smoke) up in the air.

\section{Acknowledgements}

The authors are thankful for the comments provided by academic members of the Harvard Law School; academic members of the Boston University School of Law; academic members of the William and Mary School of Law, including Professor James Dwyer; also Richard Herman, MD; and, importantly, academic members of the William S. Boyd School of Law, including Professor Mary LaFrance, and Professor Marketa Trimble. The authors sincerely thank the editors for their comments and suggestions.

\section{Conflicts of Interest}

The authors declare no conflicts of interest regarding the publication of this paper.

\section{References}

Atherton, D. (2016). As Australia Shows, Plain Packaging for Cigarettes Does Not Work. Breitbart. https://www.breitbart.com/europe/2016/09/08/plain-packaging-not-work

Burgess, A. (2015). Australia Prevails over Philip Morris in Cigarette Plain Packaging Case. The Manufacturer.

https://www.themanufacturer.com/articles/australia-prevails-over-philip-morris-in-cig arette-plain-packaging-case

Drahos, P. (1999). Intellectual Property and Human Rights. Intellectual Property Quarterly, 3, 349-371.

Fang, J., Lee, K., \& Sejpal, N. (2017). The China National Tobacco Corporation: From Domestic to Global Dragon? Global Public Health: An International Journal for Research, Policy and Practice, 12, 315-334. https://doi.org/10.1080/17441692.2016.1241293

Hinchliffe, S. (2013a). Comparing Apples and Oranges in Trademark Law: Challenging the International and Constitutional Validity of Plain Packaging of Tobacco Products. John Marshall Review of Intellectual Property Law, 13, 130.

Hinchliffe, S. (2013b). Mediating Foreign Norms and Local Imperatives: Intellectual Property "Law" as between the East and the West-From Imperial to Modern. Journal of Comparative Legal History, 1, 155-185. https://doi.org/10.5235/2049677X.1.2.155 
Inge Lengton, D. (2018). Plan Staatssecretaris Blokhuis: Sigarettenpakjes Krijgen Neutrale Kleur. De Telegraaf.

https://www.telegraaf.nl/nieuws/2499077/plan-staatssecretaris-blokhuis-sigarettenpakj es-krijgen-neutrale-kleur

Kurohi, R. (2019). Parliament: Cigarettes Packs to Be Sold in Standardised Plain Packaging. The Straits Times.

https://www.straitstimes.com/politics/parliament-cigarettes-packs-to-be-sold-in-stand ardised-plain-packaging

Landes, W. M., \& Posner, R. A. (2003). The Economic Structure of Intellectual Property Law. Cambridge, MA: Harvard University Press.

Liberman, J., \& Mitchell, A. (2010). In Search of Coherence between Trade and Health: Inter-Institutional Opportunities. Maryland Journal of International Law, 25, 143.

Mitchell, A. (2001). Broadening the Vision of Trade Liberalisation. World Competition, 24, 343-365. https://doi.org/10.1023/A:1011999624626

Mitchell, A. (2010a). Australia's Move to the Plain Packaging of Cigarettes and Its WTO Compatibility. Asian Journal of WTO and International Health Law and Policy, 5, 405-425.

Mitchell, A. (2010b). The TRIPS-Consistency of Australia's Move towards Plain Cigarette Packaging. Asian Journal of WTO and International Health Law and Policy, 5, 399.

Mitchell, A., \& Studdert, D. (2012). Plain Packaging of Tobacco Products in Australia: A Novel Regulation Faces Legal Challenge. Journal of the American Medical Association, 307, 261-262. https://doi.org/10.1001/jama.2011.2009

Mitchell, A., \& Voon, T. (2009). Patents and Public Health in the WTO, FTAs and Beyond: Tension and Conflict in International Law. Journal of World Trade, 43, 571-601.

Mitchell, A., \& Wurzberger, S. (2011). Boxed In? Australia's Plain Tobacco Packaging Initiative and International Investment Law. Arbitration International, 27, 623-652. https://doi.org/10.1093/arbitration/27.4.623

Nadel, J., Rees, V., \& Gregory, N. (2005). Disparities in Global Tobacco Harm Reduction. American Journal of Public Health, 95, 2120.

https://doi.org/10.2105/AJPH.2005.073353

Post Reporters (2018). Thailand 1st in Asia to Adopt Plain Packaging. Bangkok Post. https://www.bangkokpost.com/news/general/1597266/thailand-1st-in-asia-to-adopt-pl ain-packaging

Reuters Health News (2018). Saudi Arabia Tells WTO It Plans to Adopt Plain Tobacco Packaging. https://www.reuters.com/article/us-saudi-tobacco-idUSKCN1LS2QI

Siegel, M. et al. (1997). Preemption in Tobacco Control: Review of an Emerging Public Health Problem. Journal of the American Medical Association, 278, 858-863. https://doi.org/10.1001/jama.1997.03550100084044

Thomsen, S. (2017). It Looks like the Tobacco Industry Has Lost a Crucial Case against the Australian Government over Plain Packaging. Business Insider Australia. https://www.businessinsider.com.au/it-looks-like-the-tobacco-industry-has-lost-a-cruc ial-case-against-the-australian-government-over-plain-packaging-2017-5

Voon, T. et al. (2012). Public Health and Plain Packaging of Cigarettes: Legal Issues. Cheltenham: Edward Elgar Publishing Ltd. https://doi.org/10.4337/9781781952177

Voon, T., \& Mitchell, A. (2011a). Face Off: Assessing WTO Challenges to Australia's Scheme for Plain Tobacco Packaging. Public Law Review, 22, 218-240.

Voon, T., \& Mitchell, A. (2011b). Time to Quit? Assessing International Investment 
Claims against Plain Tobacco Packaging in Australia. Journal of International Economic Law, 14, 515-552. https://doi.org/10.1093/jiel/jgr030

Voon, T., \& Mitchell, A. (2012a). Implications of International Investment Law for Plain Tobacco Packaging: Lessons from the Hong Kong-Australia BIT. In T. Voon et al. (Eds.), Public Health and Plain Packaging of Cigarettes: Legal Issues (p. 137). Cheltenham: Edward Elgar Publishing Ltd.

Voon, T., \& Mitchell, A. (2012b). Implications of WTO Law for Plain Packaging of Tobacco Products. In T. Voon et al. (Eds.), Public Health and Plain Packaging of Cigarettes: Legal Issues (p. 109). Cheltenham: Edward Elgar Publishing Ltd.

World Health Organization (1999). WHO Framework Convention on Tobacco Control. Report of the First Meeting of the Working Group, 25-29 October 1999, Unpublished Document A/FCTC/WG1/7. 